\title{
Some Toxicological and Histopathological Changes Induced By Long- Term Administration of Tramadol in Male Rats
}

\author{
Zakaria A. El-Zawakry, Mahmoud Ismail ${ }^{1}$, and Magdy F. Abou El Fotoh ${ }^{2}$ \\ ${ }^{1}$ Department of Forensic Medicine and Toxicology, Faculty of Medicine, Zagazig University, Al sharqia, Egypt \\ ${ }^{2}$ Department of Forensic Medicine and Toxicology, Faculty of Veterinary medicine., Zagazig Univ., Al sharqia Egypt
}

\begin{abstract}
The present study investigated the effects of repeated tramadol administration on 60 male rats. The animals were randomly divided into 6 equal groups ( $n=10 /$ group). The first group served as control and received saline solution only during the study. the second, third, fourth, fifth and sixth groups were given oral doses of tramadol ( tramadol HCL) suspended in saline solution equal to 40, 80, 120,160 and 200 $\mathrm{mg} / \mathrm{kg}$ daily for 60 days. Liver and kidney functions, sex hormones activity, some neurochemical parameters in addition to some histopathological changes of the rat testis and brain tissues were studied. The results of the present experiment revealed a significant gradual increase in the serum ALT, AST and creatinine by increasing the dose of tramadol, the same result was obtained for PRL and $\mathrm{E}_{2}$ in male rats. Tramadol significantly reduced serum LH, FSH and testosterone levels gradually, where $200 \mathrm{mg} / \mathrm{kg}$ showed the lowest levels. Repeated administration of tramadol also increased the density of $\alpha_{1}-$ adrenoceptors in the rat brain cortex, as measured by saturation analysis of $\left[{ }^{3} \mathrm{H}\right]$ prazosin binding resembling the effects induced by conventional antidepressants. The histopathological examination of testis revealed severe diffused testicular degeneration, which was aggravated till testicular tissues calcification with increasing dose of tramadol (40, 80, 120, 160 and $200 \mathrm{mg} / \mathrm{kg} . b . w t$.$) . Brain tissues in all$ treated groups showed slight congestion of sub-meningeal blood vessels and neural degeneration. These findings suggest increased hepatic, renal and neurological damage and sexual dysfunction evoked by repeated administration of tramadol for long periods.
\end{abstract}

Keywords Tramadol, Biochemical toxicity, Sexual dysfunction, Histopathological changes, Rats.

\section{Introduction}

$\mathrm{T}$ Tramadol is a synthetic opioid analgesic commonly prescribed for moderate to severe pain, with doses up to $200 \mathrm{mg} / \mathrm{day}$ (McKeon et al., 2011). Its analgesic effect may be mediated by both opioid and non-opioid (i.e. norepinephrine and serotonin reuptake inhibition) mechanisms (Raffa et al., 1992; Liu et al., 1999; Nossaman et al.,2010). Clinically active tramadol is a racemic mixture of two enantiomers that have two distinct but complementary mechanisms of action: the (+) tramadol is a selective agonist for $\mu$-opioid receptor, it preferentially inhibits serotonin reuptake and enhances serotonin efflux in the brain, whereas the (-) enantiomer mainly inhibits noradrenaline reuptake (Frink et al., 1996 ; Scott and Perry, 2000).Being an opioid, tramadol carries all possible risks known from other opiates (Cicero et al., 2005; Adams et al., 2006). Side effects include dizziness, headache, somnolence, nausea, constipation, sweating, pruritus, and central nervous system stimulation (Reig, 2002; Kabel and van Puijenbroek, 2005).Tramadol causes respiratory depression, psychological and physical addiction similar to that of other opiates and the analgesic efficacy of tramadol can further be improved by combination with a non-opioid analgesic (Senay et al., 2003; Ripamontic et al., 2004; Lanier et al., 2010).However, the dependence potential of tramadol is relatively lower than that of opiates and the risk is higher in former drug abusers and medical staff personnel than in pain patients (Radbruch, et al, 2013) Young addicts typically substitute tramadol for heroin. Repeated tramadol administration in such patients might lead to the accumulation of toxic metabolites in the body, increase the risk for 
pharmacokinetic interactions, and/or decrease the clearance of tramadol, thus increasing its potential for toxicity (Tjäderborn et al., 2007; De Decker et al.,2008; Shadnia et al., 2008).

Therefore, the aim of the present study was to assess, the biochemical, pharmacological and histopathological toxicity profiles of Tramadol $\mathrm{HCl}$. Liver and kidneys functions, sex hormones activity and some neurochemical parameters were studied on male rats and brain and testis tissues were subjected to histopathological analysis.

\section{Material and methods \\ Drug}

Tramadol (tramadol HCL), $225 \mathrm{mg}$ tablets, was obtained from El-Kahera -pharm, Egypt. Its chemical name is $( \pm)$ cis-2-[(dimethylamino)methyl]-1-(3-methoxyphenyl) cyclohexanol hydrochloride.

\section{Animals and dosing}

The experiment was carried out on 60 male rats weighing 180-200 g, obtained from the animal research unit of the faculty of veterinary medicine, Zagazig University. All animals were housed in a quiet non-stressful environment for 10 days before study, they were given normal rat chow and water ad-libitum throughout the experiment. Experimental procedures were performed in accordance with the guide of the care and use of laboratory animals approved by the committee of Zagazig University, the fewest number of animals estimated to obtain valid results were used and painful procedures were conducted with appropriate sedation to avoid pain and stress. The animals were randomly distributed into 6 equal groups ( $n=10 /$ group). The first group served as control and received $2 \mathrm{ml}$ saline solution per rat daily by oral gavage. Similarly, the second, third, fourth, fifth and sixth groups were given tramadol (tramadol HCL) suspended in saline solution equal to $40,80,120,160$ and $200 \mathrm{mg} / \mathrm{kg} / \mathrm{day}$ respectively for 60 days. At the end of the experiment, each rat was euthanized by intraperitoneal injection of $200 \mathrm{mg} / \mathrm{kg}$ sodium pentobarbital euthanasia solution, followed by decapitation.

\section{Sample preparation}

Blood samples were collected in dry centrifuge tubes for serum preparation, sera were separated and preserved at $20{ }^{\circ} \mathrm{C}$ till used for analysis. The brain (cortex) was dissected out, frozen on dry ice and stored until used for $\alpha_{1}$-adrenoceptors binding experiments after preparation of the tissue homogenate. Brain and testis specimens were isolated and rinsed in phosphate buffer solution ( $\mathrm{PH}$ 7.5), and fixed in phosphate buffered formalin for histopathological examination.

\section{Biochemical analysis}

\section{1- Liver, kidney function parameters and sex hormones} activities:

-Aminotransferases (ALT, AST) activities were measured using the method of (Thomas, 1998).

-Creatinine (creat.) was determined using the method of Fossati et al., (1983).

-Luteinizing hormone ( $\mathrm{LH})$, follicle stimulating hormone (FSH), prolactin (PRL), testosterone (Tes) and estradiol
$\left(\mathrm{E}_{2}\right)$ were determined using enzyme linked immunosorbant assay (ELISA) kits according to manufacturer instructions.

\section{2- $\alpha_{1}$-adrenoceptors binding in the rat brain cortex.}

The experiment was carried out according to the method of Rogo'z' et al., (2001).

\section{Histopathological study}

Specimens collected from brain and testis were fixed in phosphate buffered formalin, used for preparation of sections, stained with hematoxylin and eosin (H\&E), and processed for histopathological examination using light microscope according to Bancroft and Gamble (2002).

\section{Statistical analysis}

Data of the current study was statistically analyzed using the computer program SPSS/PC (2001). The statistical method was one way ANOVA test followed by LSD.

\section{Results}

As shown in (Table 1); there were highly significant elevations $(p<0.01)$ of alanine aminotransferase (ALT) and aspartate aminotransferase (AST) in all groups that received tramadol $(\mathrm{F}=43.8$ and 73.5 respectively). However, among treated groups, significance of that increase in levels was noted in group $\mathrm{V}$ when compared all other groups. Also creatinine level was significantly elevated $(p<0.05)$ in all treated groups when compared with the control group $(\mathrm{F}=7.2)$, indicating toxicity induced by tramadol administration as seen in table (2).

There was a significant increase in $\mathrm{E}_{2}$ and PRL levels ( $\mathrm{p}<0.01)$ compared to control $(\mathrm{F}=28.4$ and 313.6 respectively), while the administration of tramadol resulted in a highly significant reduction in testosterone level $(\mathrm{p}<0.01)$ accompanied with gradual reduction in LH and FSH levels $(\mathrm{p}<0.01)$ compared to control $(\mathrm{F}=$ $110.1,48.6$, and 81.4 respectively), these changes became more observable by increasing the dose of the drug, as shown in table (3).

Both the density $\left(\mathrm{B}_{\text {max. }}\right)$ and the affinity $(\mathrm{Kd})$ of $\alpha_{1}$-adrenoceptors in the rat brain cortex were significantly $(\mathrm{p}<0.01)$ and gradually increased with increasing the dose of tramadol, where group VI showed the highest density and affinity compared to control, followed by the group V and IV which were nearly equal to each other, then III and II groups which also showed non-significant changes between them. Affinity of $\alpha_{1}-$ adrenoceptors for an agonist (Ki) as measured using phenylephrine competition for $\left[{ }^{3} \mathrm{H}\right]$ binding sites was not affected $(\mathrm{p}>0.05)$ by tramadol administration even in high doses, table (4).

\section{Histopathological findings}

Control Group I : Normal H\&E for all studied tissues in control group.

Testis: Regarding tramadol treated groups the following changes were noted:

Congestion of blood vessels in tunica vaginalis with focal hemorrhage was detected in group II (Fig.2), while focal testicular degeneration and vaculated spermatocytes were seen in group III (Fig. 3). In addition, atrophy of seminefrous tubules was detected starting from group IV on (Fig. 4). Such change became extensive and 
associated with interstitial calcification in group V (Fig. 5) and arrest of spermatogenesis in group VI (Fig. 6) representing dose dependent tramadol related testicular damage.

Brain: Regarding tramadol treated groups the following changes were noted:

Vascular changes started to appear as early as the second group where slight congestion of submeningeal blood vessels was detected (Fig. 8). Such changes beame more evident and progressed to hemorrhage as tramadol dose increased as seen in group IV (Fig. 10) and group VI (Fig. 13).

Tramadol-related neurological lesions were also detected and escalated from focal areas of gliosis infilterated by mature lymphocytes, as seen in group III (Fig. 9) to degeneration of neurons as detected in group IV (Fig. 11) up to extensive neuronal damage of purkinje cells of cerbellum as evident in group VI (Fig. 13).

Table (1): Analysis of variance (ANOVA) of tramadol effect on liver enzymes (ALT \& AST).

\begin{tabular}{|c|c|c|c|c|c|c|}
\hline Items & Control & Group II & Group III & Group IV & Group V & Group VI \\
\hline ALT (U/L) & $35.60 \pm 2.11$ & $56.20 \pm 1.20^{* *}$ & $61.35 \pm 1.60^{* *}$ & $66.45 \pm 2.35^{* *}$ & $75.0 \pm 1.69 * *$ & $79.80 \pm 1.25 * *$ \\
\hline AST (U/L) & $127.50 \pm 2.50$ & $206.30 \pm 2.65 * *$ & $209.55 \pm 2.44 * *$ & $216.95 \pm 2.50 * *$ & $222.13 \pm 2.19 * *$ & $228.75 \pm 1.90 * *$ \\
\hline
\end{tabular}

**: Highly significant at $p<0.01$

Table (2): Analysis of variance (ANOVA) of tramadol effect on creatinine level of mature male albino rats.

\begin{tabular}{|c|c|c|c|c|c|c|}
\hline Items & Control & Group II & Group III & Group IV & Group V & Group VI \\
\hline Creatinine & $0.42 \pm 0.19$ & $0.57 \pm 0.25 *$ & $0.59 \pm 0.29 *$ & $0.60 \pm 0.32 *$ & $0.62 \pm 0.41 *$ & $0.63 \pm 0.35 *$ \\
\hline
\end{tabular}

*: Significant at $<0.05$

Table (3): Analysis of variance (ANOVA) of tramadol effect on gonadol hormones of mature male albino rats.

\begin{tabular}{|c|c|c|c|c|c|c|}
\hline Items & Control & Group II & Group III & Group IV & Group V & Group VI \\
\hline LH $(\mathrm{ml} \mathrm{U} / \mathrm{ml}$ & $2.40 \pm 0.20$ & $1.90 \pm 0.50 * *$ & $1.65 \pm 0.42 * *$ & $1.35 \pm 0.35 * *$ & $0.95 \pm 0.22 * *$ & $0.76 \pm 0.15 * *$ \\
\hline FSH $(\mathrm{ml} \mathrm{U} / \mathrm{ml}$ & $2.20 \pm 0.15$ & $1.50 \pm 0.40 * *$ & $0.99 \pm 0.44 * *$ & $0.85 \pm 0.30 * *$ & $0.76 \pm 0.21 * *$ & $0.55 \pm 0.11 * *$ \\
\hline Testosterone $(\mathrm{mg} / \mathrm{ml})$ & $4.40 \pm 0.44$ & $2.95 \pm 0.56^{* *}$ & $2.10 \pm 0.45^{* *}$ & $1.80 \pm 0.60 * *$ & $1.26 \pm 0.19 * *$ & $0.85 \pm 0.13 * *$ \\
\hline Estradiol $(\mathrm{pg} / \mathrm{ml})$ & $46.30 \pm 1.55$ & $47.15 \pm 0.35 *$ & $50.85 \pm 0.20 * *$ & $53.95 \pm 0.19 * *$ & $59.10 \pm 0.33 * *$ & $62.0 \pm 0.25 * *$ \\
\hline Prolactin $(\mu \mathrm{g} / \mathrm{ml})$ & $6.90 \pm 1.35$ & $10.15+0.55 * *$ & $12.65+0.65 * *$ & $15.95+1.12 * *$ & $17.85 \pm 1.45 * *$ & $19.00+1.55^{* *}$ \\
\hline
\end{tabular}

*: Significant at <0.05, **: Highly significant at $p<0.01$

Table (4): Analysis of variance (ANOVA) of tramadol effect on binding of $\left({ }^{3} \mathrm{H}\right)$ prazosin to $\alpha_{1}-$ adrenoceptors - in the mature male albino rat.

\begin{tabular}{|c|c|c|c|c|c|c|}
\hline Items & Control & Group II & Group III & Group IV & Group V & Group VI \\
\hline $\begin{array}{c}\mathrm{B}_{\text {max. }} \\
(\mathrm{Fmol} / \mathrm{mg} \text { protein })\end{array}$ & $21.15 \pm 0.85$ & $24.20 \pm 0.15^{* *}$ & $27.35 \pm 0.35^{* *}$ & $29.90 \pm 0.65^{* *}$ & $30.45 \pm 0.50^{* *}$ & $35.45 \pm 0.20 * *$ \\
\hline $\mathrm{Kd}(\mathrm{n} \mu)$ & $0.29 \pm 0.24$ & $0.31 \pm 0.55$ & $0.34 \pm 0.45^{*}$ & $0.37 \pm 0.75^{* *}$ & $0.40 \pm 0.25^{* *}$ & $0.45 \pm 0.35^{* *}$ \\
\hline $\mathrm{Ki}(\mu \mathrm{M})$ & $2.37 \pm 0.47$ & $2.39 \pm 0.48$ & $2.38 \pm 0.47$ & $2.40 \pm 0.49$ & $2.37 \pm 0.47$ & $2.39 \pm 0.48$ \\
\hline
\end{tabular}

*: Significant at <0.05, **: Highly significant at $p<0.01$

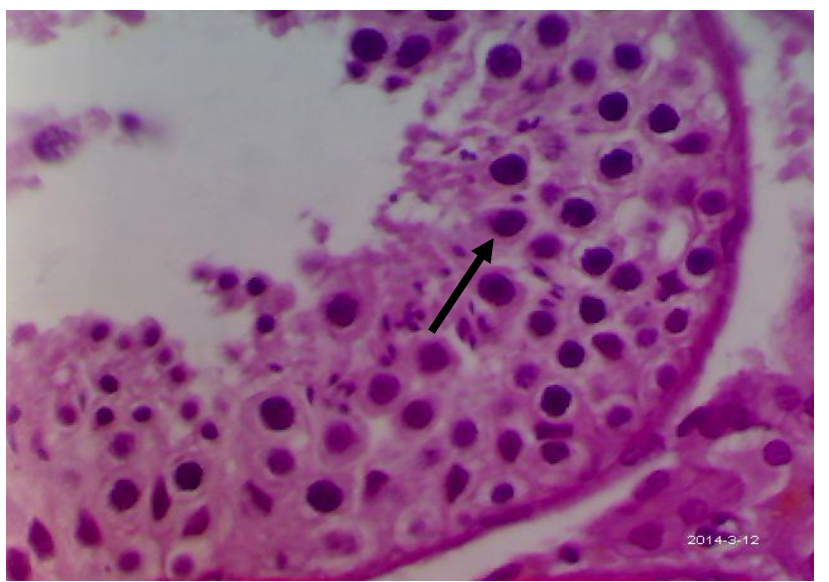

Fig. (1): Photomicrograph of testis section of control male albino rats showing normal seminferous tubules lining spermatocytes and spermatogenesis $(\mathrm{H} \& \mathrm{E}, \mathrm{X}$ 100)

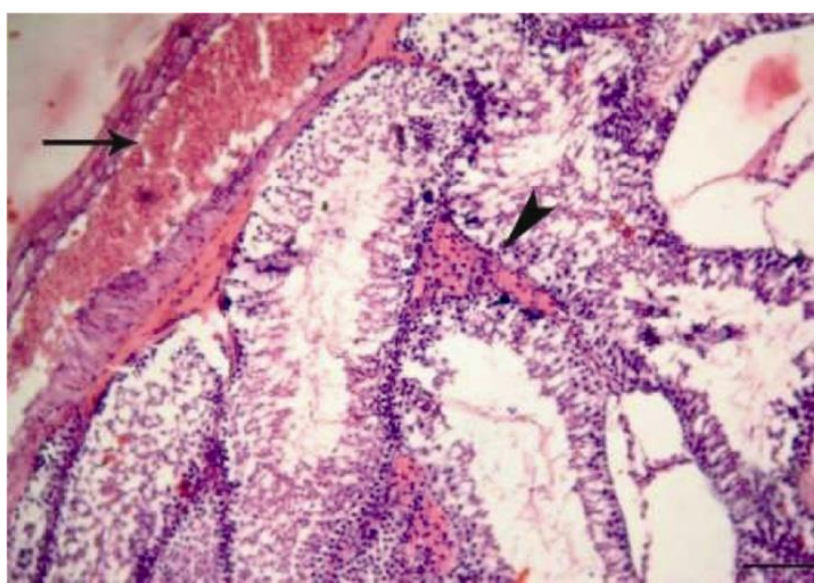

Fig. (2): Photomicrograph of testis section of $40 \mathrm{mg}$ tramadol treated group showing congestion of blood vessels in tunica vaginalis which was focally hemorrhagic (H \& E, x 100) 


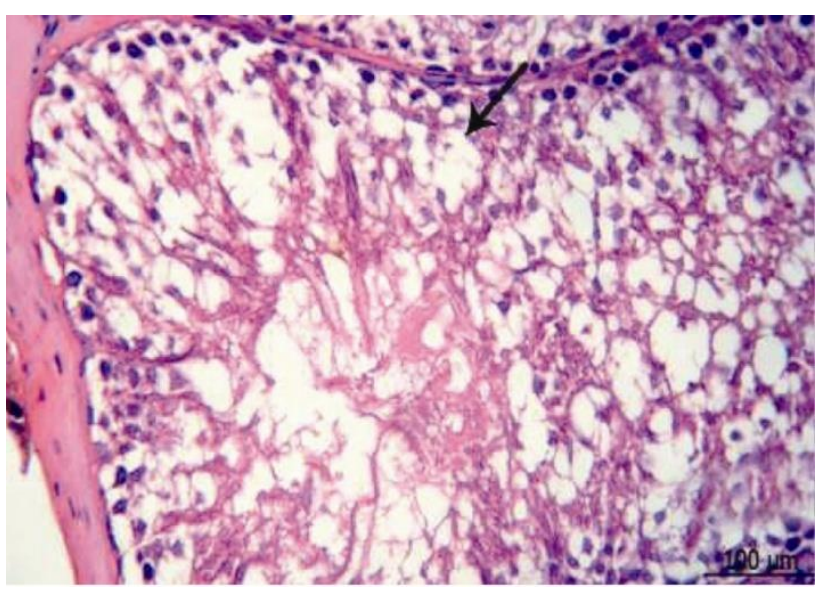

Fig. (3): Photomicrograph of testis section of $80 \mathrm{mg}$ tramadol treated group showing focal testicular degeneration with single or multiple layer of vaculated spermatocytes with a little evidence of spermatogenersis (H \& E, X100)

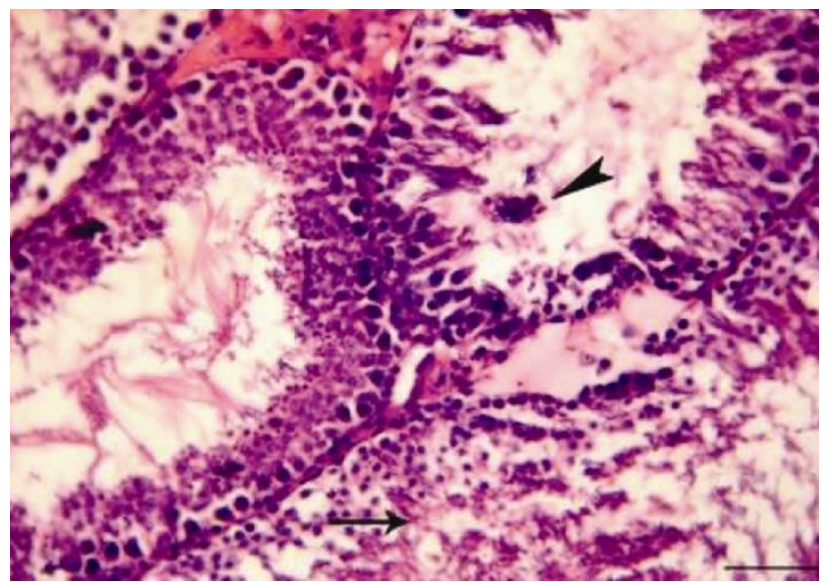

Fig. (5): Photomicrograph of testis section of $160 \mathrm{mg}$ tramadol treated group showing atrophy of seminefrous tubules with interstitial calcification $(\mathrm{H} \&$ E, X100)

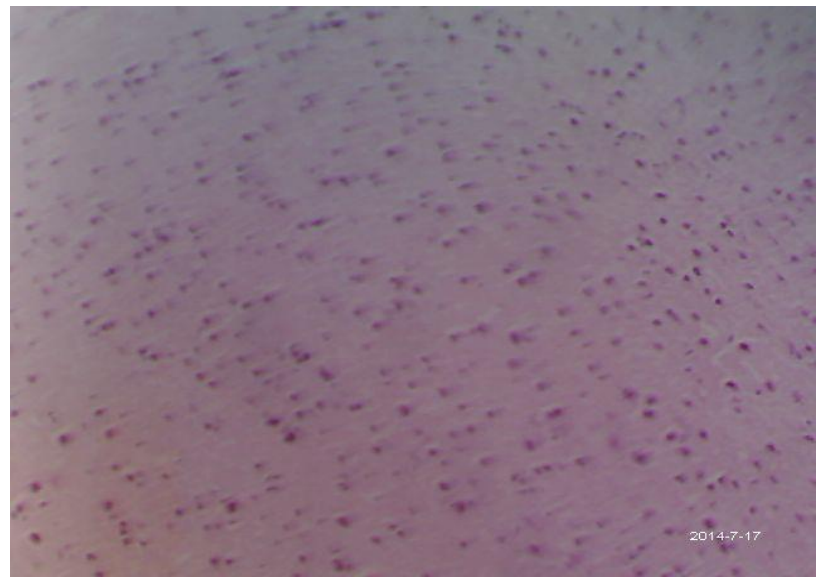

Fig. (7): Photomicrograph of bran section of control group showing normal brain tissue.

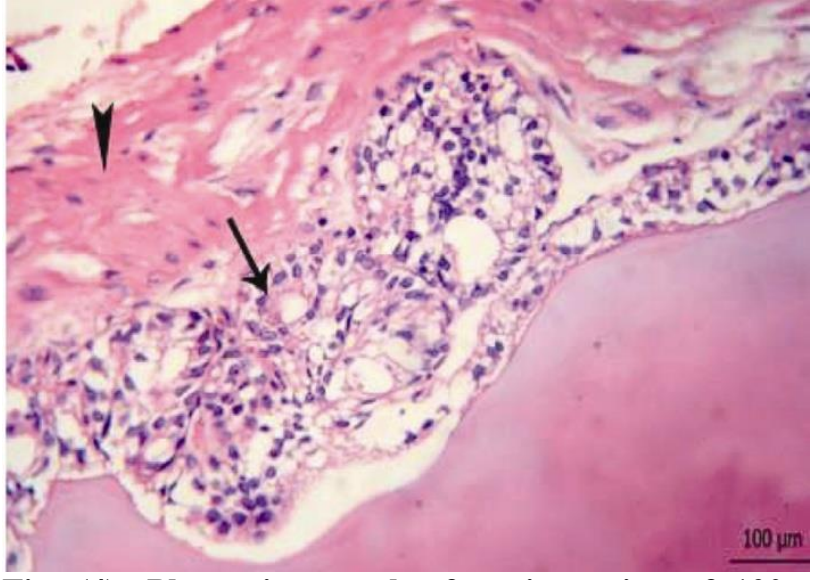

Fig. (4): Photomicrograph of testis section of $120 \mathrm{mg}$ tramadol treated group showing edema and atrophy of seminefrous tubules (H \& E, X100)

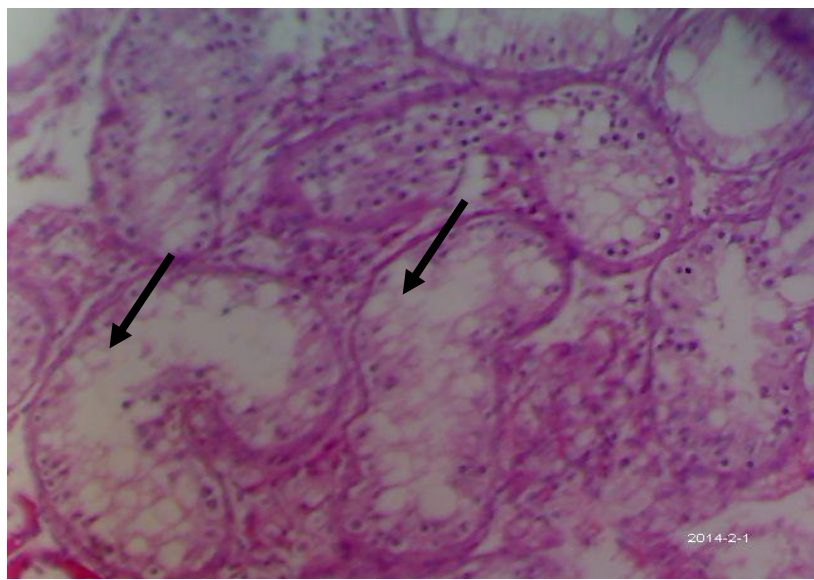

Fig. (6): Photomicrograph of testis section of $200 \mathrm{mg}$ tramadol treated group showing arrest of spermatogenesis and degeneration with interstitial calcification (H \& E, X100)

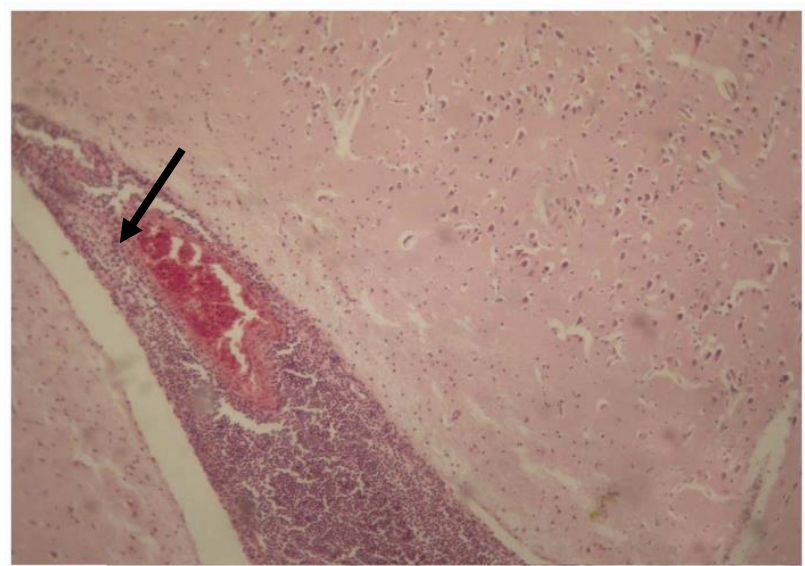

Fig. (8): Photomicrograph of brain section of $40 \mathrm{mg}$ tramadol treated group showing dilated and congested thin walled blood vessel effused by many lymphocytes ( $H$ \& E, X100) 


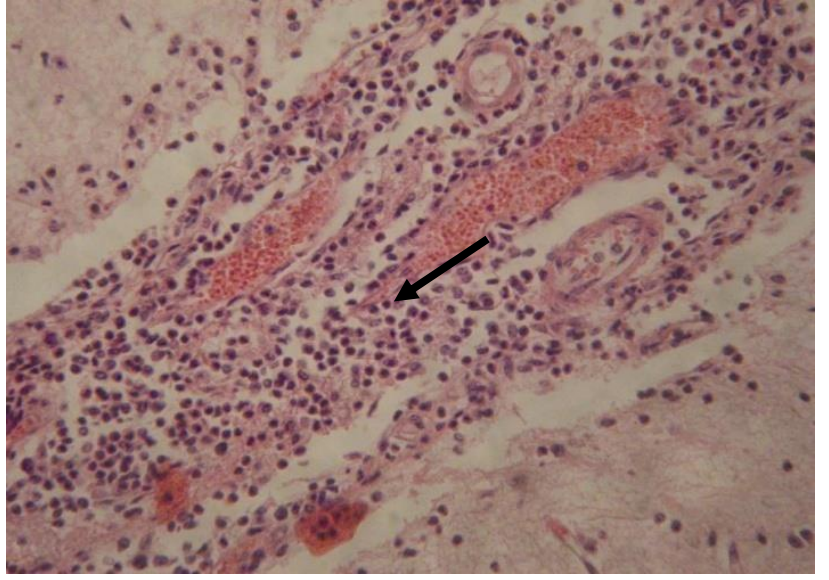

Fig. (9): Photomicrograph of brain section of $80 \mathrm{mg}$ tramadol treated group showing focal area of gliosis infiltrated by mature lymphocytes (H \& E, X100)

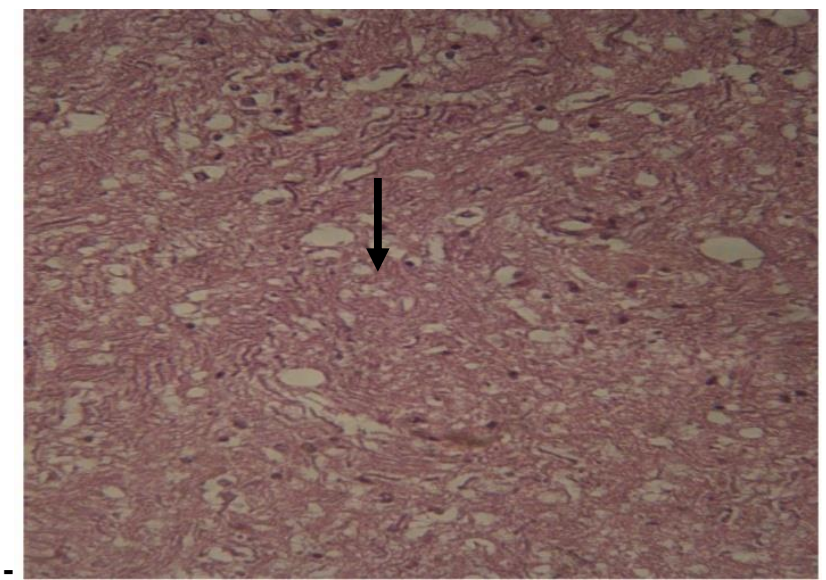

Fig. (11): Photomicrograph of brain section of $120 \mathrm{mg}$ tramadol treated group showing degenerated neurons $(\mathbf{H}$ $\& \mathrm{E}, \mathrm{X100)}$

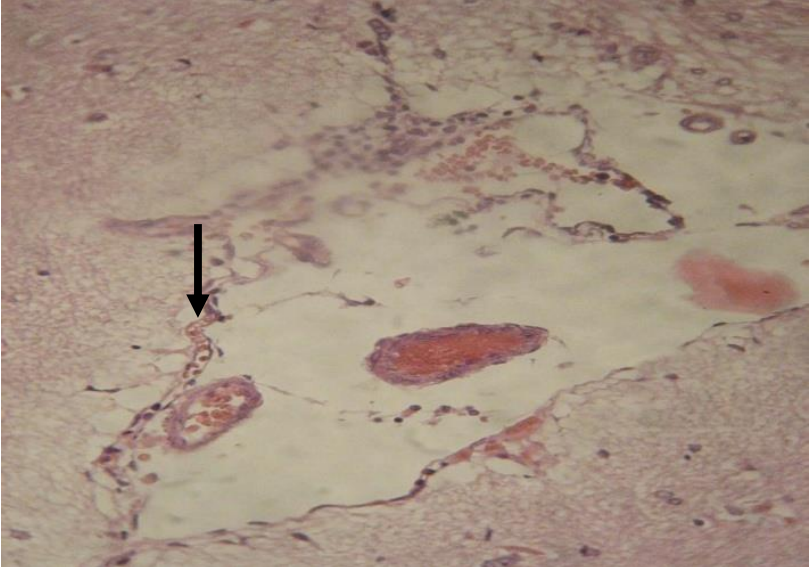

Fig. (10): Photomicrograph of brain section of $120 \mathrm{mg}$ tramadol treated group showing congestion of blood vessels extravasated RBCs (hemorrhage) (H \& E, X100)

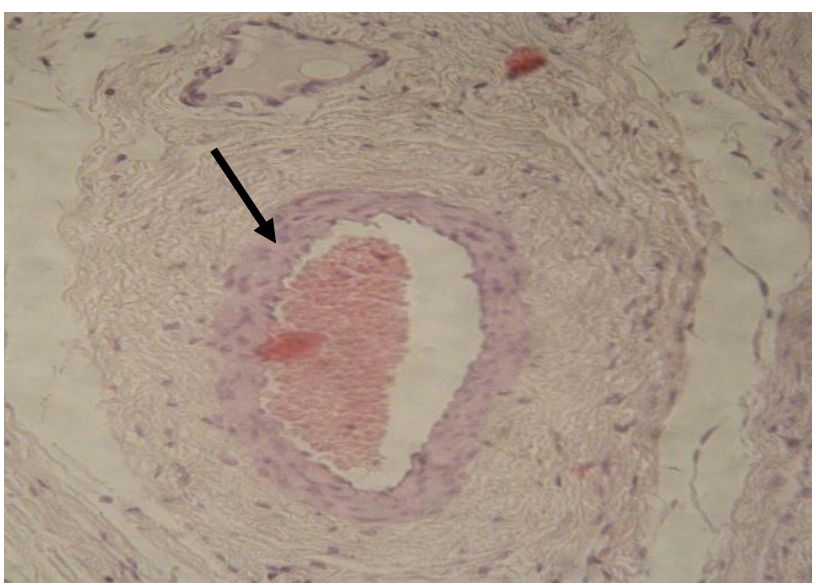

Fig. (12): Photomicrograph of brain section of $160 \mathrm{mg}$ tramadol treated group showing congested meningeal blood vessels (H \& E, X100)

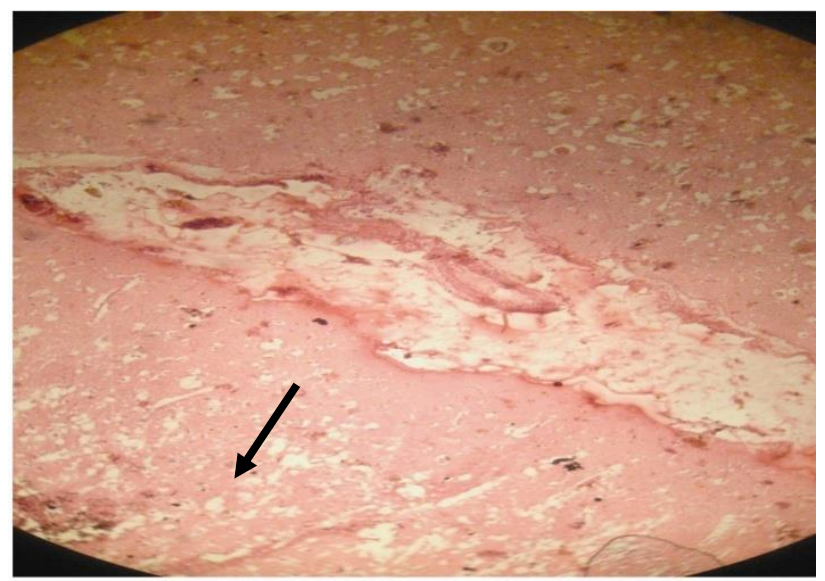

Fig. (13): Photomicrograph of brain section of $200 \mathrm{mg}$ tramadol treated group showing degenerated neurons and hemorrhagic infiltration $(H \& E, X 100)$ 


\section{Discussion}

Hepatic metabolism is a mechanism that converts drugs and other compounds into products that are more easily excreted and that usually have a lower pharmacological activity than the parent compound (Tolman, 1998). A metabolite may have higher activity and / or greater toxicity than the original drug. Metabolites of the drugs that are excreted via kidneys may also cause cellular damage leading to kidney dysfunction (Singhal et al., 1998).

In the present study, tramadol induced dosedependent significant increase in ALT and AST levels. These results are in contrast with Habibian-Dehkordi et al., (2010), who found that short term intravenous administration of tramadol had no effect on ALT, AST, and ALP levels.

Results of the present study are comparable with the findings of Borzelleca et al., (1994) who reported increased ALT, AST activities in rats after long term administration of morphine like agent Levo-alphaacetylmethadol HCL (LAAM) and also among heroin users (Panchenko et al., 1999) and similar to the results of El-Gaafarawi., (2006) who recorded a significant increase in the ALT and AST activities in rats after administration of $40 \mathrm{mg} / \mathrm{kg}$ b.wt. and $80 \mathrm{mg} / \mathrm{kg}$ b.wt. tramadol in comparison with control group.

In the same context current results indicate a gradual increase in creatinine levels with increasing tramadol dose, this is also in accordance with results of Atici et al., (2005) and El-Gaafarawi., (2006) who reported increased creatinine levels after tramadol administration for a long period.

The above observations may be confirmed by the suggestions of Wu et al., 2001 and Jassen-ortho inc., 2005 who stated that liver and kidney are responsible for tramadol metabolism and excretion, so it may cause hepatotoxicity and nephrotoxicity.

Opiate use is known to decrease the levels of sex hormones in both sexes and this is thought to be responsible for the diminished fertility of both male and female opiate users Mckim (2003).

The present study showed that tramadol treated rats had lowered plasma levels of testosterone, $\mathrm{LH}$ and FSH, and significantly increased prolactin levels compared with control rats. The decreased plasma FSH and LH levels were explained by Bliesener et al. (2005), who showed that a part of the opioid effect on gonadotropin-releasing hormone $(\mathrm{GnRH})$ is through the increased levels of prolactin. Pimpinelli et al. (2006) added that when prolactin levels increase, testosterone synthesis could be directly inhibited.

The transformation of testosterone into estradiol is due to the enzyme aromatase. The present study showed low testosterone and high estradiol levels. Also considering the testosterone -to-estradiol ratio, it was higher in the control group than in the high dose groups. This finding was explained by Ceccarelli et al. (2006), who reported that in addition to decreasing testosterone production, morphine, tramadol and buprenorphine also increase aromatization of testosterone to estradiol.

The present results support previous studies concerned with gonadal activity during drug abuse where Chowdhury (1987) reported decreased levels of LH and testosterone with increased prolactin hormone after morphine and methadone administration. Also ElGaafarawi et al (2005) and El-Gaafarawi., (2006) observed the reduction of serum levels of LH, FSH and testosterone and the induction of prolactin hormone (PRL) and E2 secretion after paroxetine and tramadol treatment respectively.

Similar results for reduced testosterone and elevated E2 have been reported by Herzog et al. (2004). Also, Marwa and Adel (2014) concluded that tramadol treatment affects the testicular function of adult male rats and these effects may be through overproduction of NO and oxidative stress induced by this drug.

In the present study, histopathological findings in testicular tissues of tramadol treated groups support the laboratory evidence of sexual dysfunction. These results are in accordance with Mckim (2003) who stated that opiate use is known to diminish fertility of both male and female users.

The current work also examined tramadol effect on brain and results showed that upon treatment with tramadol the density and the affinity of $\alpha_{1_{-}}$adrenoceptors in the rat brain cortex was increased, these findings are similar to those of Goreska et al., (2004) who found that repeated administration of tramadol $(20 \mathrm{mg} / \mathrm{kg} / \mathrm{wt}$ for 21 days) increased the density of $\alpha_{1}$-adrenoceptors in the rat brain cortex, as measured by saturation analysis of $\left[{ }^{3} \mathrm{H}\right]$ prazosin binding . Our results are confirmed by the histopathological alterations observed in the brain tissue of rats from all treated groups compared to control group.

\section{Conclusion and Recommendations:}

Tramadol exerts toxic effects on neurological, hepatic, renal and sexual functions. Physicians should be aware of aforementioned adverse effects and. Dose selection should be cautious. The authors recommend that patients on long term tramadol therapy should be screened routinely for laboratory abonormalities in liver, kidney and sex hormones. Awareness campaigns should be conducted to the population about such hazards of tramadol abuse.

\section{References}

Adams, E.H.; Breiner, S.; Cicero, T.J.; Geller, A.; Inciardi, J.A.; Schnoll, S.H.; Senay, E.C. and Woody, G.E. (2006): A comparison of abuse liability of tramadol, NSAIDs, and hydrocodone in patients with chronic pain. J. pain Symptom Manage., 31(5): 465-476.

Atici S., I. Cinel, L. Cinel, N. Doruk, G. Eskandari and V. Oral (2005): Liver and kidney toxicity in chronic use of opioids: An experimental long term treatment model, J. Biosci. 30 (2): 245252 . 
Baneroft, J.D. and Gamble, M. (2002): "Theory and practice of histological technique" $\left(5^{\text {th }}\right.$ d. $)$. Churchill Livingstone, Edinburg and London.

Bliesener N, Albrecht S, Schwager A, Weckbecker K, Lichtermann D, Klingmüller D (2005). Plasma testosterone and sexual function in men receiving buprenorphine maintenance for opioid dependence. J. Clin. Endocrinol. Metab.; 901: 203-6.

Borzelleca, J.F.; Egle, L.S.; Harries, D.N.; Johnson, J.B.; Terrill and Belleville, J.A. (1994): Toxicological evaluation mu-agonists. Part 1: Assessment toxicity following 30 days of repeated oral dosing of male and female rats with levo-alpha -acetylmethadol $\mathrm{HCl}$ (LAAM). J. Apple. Toxicol. 14: 435-446.

Ceccarelli I, De Padova AM, Fiorenzani P, Massafra C, Aloisi AM(2006). Single opioid administration modifies gonadal steroids in both the CNS and plasma of male rats. Neuroscience; 140: 92937.

Chowdhury, A.R. (1987): Effects of pharmacological agents on male reproduction. Adv contracept. Deliv. Syst., 3(4): 347-52.

Cicero T.J.; Inciardi J.A.; Adams E.H.; Geller A.; Senay E. C.; Woody G.E. and Munoz S.A. (2005): Rates of abuse of tramadol remaine unchanged with the introduction of new braned and generic products: results of an abuse monitoring system, 1994-2004. Pharmacoepidemiol. Drug Saf., 14(12):851859.

De Decker K,; Cordonnier J,; Jacobs W,; Coucke V,; Schepens P,and Jorens P, G, (2008): Fatal intoxication due to tramadol alone: case report and review of the literature. Forensic Sci. Int., 25:175(1):79-82.

El- Gaafarawi, I.I.M.; Hassan, G.B.; Fouad, G. and El Komey, F. (2005): Toxic effects of paroxetine on sexual and reproductive functions of rats. The Egyptian Journal of Hospital Medicine. 21: 16-32.

El-Gaafarawi I.I, (2006): Biochemical toxicity induced by tramadol administration in male rats. The Egyptian Journal of Hospital Medicine Vol., 23: $353-362$.

Fossati, P. Prencipe, L. and Berti, G. (1983): Enzymatic creatinine assay, a new colormitric method based in $\mathrm{H}_{2} \mathrm{O}_{2}$ measurment. Clinical Chemistry, 29:1494

Frink, M.Ch., Hennies, H.-H., Englberger, W., Haurand, M., Wilffert, B. (1996): Influence of tramadol on neurotransmitter systems of the rat brain. Drug Res. 46 (II), 1029-1036.

Go'recka A.F., M. Kus'mider, S. Y. Inan, J. Siwanowicz, Teresa P., Marta D. -W. (2004): Long-term exposure of rats to tramadol alters brain dopamine and $\alpha_{1}$-adrenoceptors function that may be related to antidepressant potency,
European Journal of Pharmacology 501 103110.

Habibian- Dehkordi S, Bigham-Sadegh A, Abaspour A, Beigi Brojeni N (2010). Intravenous administration of tramadol hydrochloride in sheep. J Comp Clin Pathol. 21: 289- 293.

Herzog A.G., F.W. Drislane, D.L. Schomer, P. B. Pennell et al. (2004):Differntial effects of antiepileptic drugs on sexual function and reproductive horm-ones in men with epilepsy: interim analysis of a comparison between lamotrigine and enzyme inducing antiepileptic drugs. Epilepsia, 45(7): 764-768.

Janssen-Ortho Inc.(2005): Tramacet, a product monograph., pp.1-36, www.Janssen- ortho.com.

Kabel L, S, and van Puijenbroek E, P,(2005): Side effects of tramadol: 12 years of experience in the Netherlands. Ned. Tijdschr Geneeskd., 149(14):754-757.

Lanier, R.K.; Lofwall, M.R.; Mintzer, M.Z.; Bigelow, G.E. and Strain, E.C. (2010): Physical dependence potential of daily tramadol dosing in humans. Psychopharmacol., 211(4): 457-466.

Liu Z., Zhou W., Lian Z., Muy Ren Z., Cao Q., Cai Z. (1999). : Drug dependence and abuse potential of tramadol. Acta Pharmacol Sin ;20:52-4.

Marwa A. Ahmed and Adel Kurkar (2014): Effects of Opioid [Tramadol. treatment on testicular functions in adult male rats:Role of oxidative stress:Role of nitric oxide and oxidative stress. Clinical and Experimental Pharmacology and Physiology (2014); 41,317-323

McKeon G.P., Pacharinsak C., Long C.T., Howaed A.M., Jampacchaisari K., Yeomans D.C., Felts, A. (2011): Analgesic effects of tramadol, tramadolGama pentin and burprenorphin in an incisional model of pain in rats. J. Biol. Chem., 286 (18): 16186-96.

Mckim, W.A. (2003): Drug and behavior, an introduction to behavioral pharmacology prentice Hall New Jersy, $5^{\text {th }}$ ed. P.243.

Nossaman V. E., Ramadhyani U., Kadowitz P.J., Nossaman B.D. (2010) : Advances in perioperative pain management: use of medications with dual analgesic mechanisms, tramadol and tapentadol. Anesthesiol Clin; 28:647-66.

Panchenko L. F., S.V. Pirozhkov, A.V. Nadezhdin, V.I. Baronets and N.N. Usamanova (1999): Lipid peroxidation, peroxyl radical-scavenging system of plasma and liver and heart pathology in adolescence heroin users. Vopr.Med. Khim.45:501-506.

Pimpinelli F, Parenti M, Guzzi F, Piva F, Hokfelt T, Maggi R (2006). Presence of delta opioid receptors on a subset of hypothalamic gonadotropin releasing hormone $(\mathrm{GnRH})$ neurons. Brain Res.; 1070: 15-23. 
Radbruch L, Glaeske G, Grond S, Munchberg F, Scherbaum N, Storz E, Tholen K, ZagermannMuncke , Zieglgansberger W, HoffmannMenzel H, Greve H, Cremer-Schaeffer P (2013). Topical review on the abuse and misuse potential of tramadol and tilidine in Germany. Subst Abus 34(3): 313-320

Raffa R.B., E. Friderichs, W. Reimann, R.P. Shank, E.E. Codd and J.I. Vaught (1992): Opioid and nonopioid components independently contribute to the mechanism of action of tramadol, an "atypical" opioid analgesic. J. Pharmacol. Exp. Ther., 260 (1): 275-285.

Reig E, (2002): Tramadol in musculo-skeletal pain a survey. Clin Rheumatol., 21(1):S9-11.

Ripamontic C.; Fagnoni E. and De Conno F., (2004): Withdrawal syndrome after delayed tramadol intake. Am. J. Psychiatry, 161(12):2326-2327.

Rogoz, R.; Skuza, G.; Diaboga, D. and DziedzickaWasylewska, M. (2001): Effect of repeated treatment with tianeptine and fluoxetine on the central $\alpha_{1}$-adrenergic system Neuropharmacology, 41, 360-368.

Scott, L.J., Perry, C.M., (2000). Tramadol: a review of its use in postoperative pain. Drugs 60, 139-176.

Senay, E. C.; Adams, E. H.; Geller, A.; Jnciardi, J. A.; Munoz, A.; Schnoll, S.H.; Woody, G. E. and Cicero, T. J. (2003): Physical dependence on Ultram (tramadol hydrochloride)/: both opioid like and a typical withdrawal symptom occur. Drug Alcohol. Depend., 69(3):233-241.

Shadnia, S.; Soltaninejad, K.; Heydari, K.; Sasanian, G. and Abdollah, M. (2008): Tramadol intoxication: a review of 114 cases. Hum. Exp. Toxicol., 27(3): 201-5.

Singhal, P.C.; Sharma, V.; Sanwal, N.; Prassad, A.; Kapasi, R.; Ranjan, N.; Franki, K.; Reddy, P. and Gibbons, N. (1998): Morphine modulates proliferation of kidney fibroblasts. Kidney Int., 53:350-357.

SPSS (2001): SPSS/PC+ (2001), for the PC/XT. SPSS INC.

Thomas L.(1998): Alanine aminotransf-erase (ALT), aspartate aminotrasferase (AST), in Thomas, L. editor. Clinical Lab-oratory Diagnostics. Frankfurt: TH-Books Verlagsgesellschaft, $1^{\text {st }}$ ed., pp.55-56.

Tjäderborn M,; Jönsson A, K,; Hägg S,; Ahlner J, (2007): Fatal un-intentional intoxications with tramadol during 199-2005. Forensic Sci. Int., $173(2-3): 107-11$.

Tolman K.G. (1998): Hepatotoxicity of non-narcotic analgesics. Am. J. M., 105(1B): 13S-19S.

Wu W.N., L.A. Mcknown, A. D. Gauthier, W.J. Jones and R.B. Raffa (2001): Metabolism of analgesic, tramadol hydrochloride, in rat and dog. Xenobiotica, 31: 423-441.

\section{الملخص العربي}

\section{بعض التغيرات السمية والهستوباثولوجية المحدثة بالتعاطي طويل الامد للترامادول فى ذكور الفئران زكريا الظواهري و محمود العوضي اسماعيل' و مجدي ابوالفتوح'}

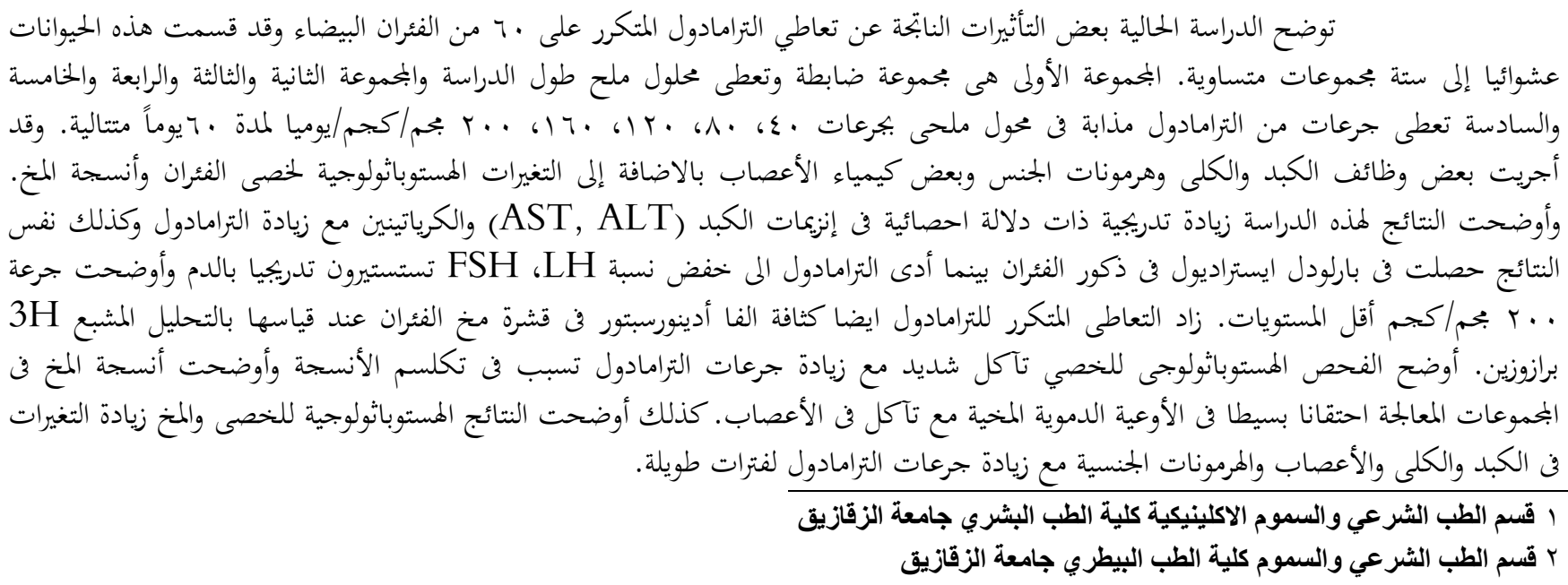

